\title{
(-⿶凵⿴囗十)
}

Citation:

Branney, P and Hiley, C (2010) Reply by the Authors. Urology, 75 (3). 751 - 752 . ISSN 0090-4295

DOI: https://doi.org/10.1016/j.urology.2009.12.005

Link to Leeds Beckett Repository record:

https://eprints.leedsbeckett.ac.uk/id/eprint/511/

Document Version:

Article (Accepted Version)

The aim of the Leeds Beckett Repository is to provide open access to our research, as required by funder policies and permitted by publishers and copyright law.

The Leeds Beckett repository holds a wide range of publications, each of which has been checked for copyright and the relevant embargo period has been applied by the Research Services team.

We operate on a standard take-down policy. If you are the author or publisher of an output and you would like it removed from the repository, please contact us and we will investigate on a case-by-case basis.

Each thesis in the repository has been cleared where necessary by the author for third party copyright. If you would like a thesis to be removed from the repository or believe there is an issue with copyright, please contact us on openaccess@leedsbeckett.ac.uk and we will investigate on a case-by-case basis. 


\section{Reply by the Authors}

TO THE EDITOR:

Mr. Carson makes several important and pithy points with which we agree. However, there is 1 overarching point that we read into his response to our article "Choosing Health, Choosing Treatment: Patient Choice After Diagnosis of Localized Prostate Cancer,"1 that how health services are to support patients in making choices is still to be decided and is therefore an important point of discussion. To continue this discussion, we want to follow-up Carson's comment about the role of nurses in supporting patient choice and his suggestion about in- cluding clinical epidemiologists in multidisciplinary teams (MDTs).

Please forgive us if we gave the impression that a clinical nurse specialist would be unbiased when discussing treatment options. We would not wish to suggest that anyone-nurses, medical students, clinical epidemiologists-could transcend their subjectivity to become objective. Rather than asking who will be least biased, we should instead consider the implementation of processes that will better allow health professionals to support patients in their decision-making. The qualitative research of recruitment into the ProtecT trial ${ }^{2}$ may prove particularly important because it provides suggestions for achieving equipoise in the presentation of treatment options.

The suggestion that Clinical Epidemiologists may sup- port MDTs is interesting. One would hope that the practice of evidence-based medicine (EBM) is now the bedrock of clinical decision-making. Perhaps clinicians need support from a designated expert to search evidence for immediate clinical application. We wonder if research on patients' experiences and other qualitative evidence would add much of practical benefit for an MDT to consider. Unfortunately, those that attempt to search for research on patients' experiences will find that there is little to help them yet. One resource, for example, http://healthtalkonline.org (previously the database of pa- tients' experiences; DIPEx), will be useful for health professionals and patients alike. Perhaps we could substi- tute clinical epidemiology with research on patients' ex- periences, or find some way to integrate them. Localized prostate cancer is all about uncertainty. Current clinical knowledge does not yet translate into information that comes close to resolving decisional doubt or conflict.

\section{References}


1. Branney $P$, White $A$, Jain $S$, et al. Choosing health, choosing treatment: patient choice after diagnosis of localized prostate cancer. Urology. 2009;74:968-971.

2. Donovan J, Mills N, Smith M, et al. Improving design and conduct of randomised trials by embedding them in qualitative research: ProtecT (prostate testing for cancer and treatment) study. BMJ. 2002;325:766-770.

Peter Branney, Ph.D., C.Psychol., C.Sci.

Centre for Men's Health, Leeds Metropolitan University Leeds, United Kingdom

Chris Hiley, Ph.D., C.Sci.

London, United Kingdom 